\title{
An Analysis of Teacher's Speech Acts in Teaching and Learning Process
}

\author{
Widi Andewi ${ }^{1}$, Winia Waziana ${ }^{2}$ \\ widiandewi.91@gmail.com ${ }^{1}$,winiawaziana@gmail.com² \\ STMIK Pringsewu
}

\begin{abstract}
This research focuses on classroom interaction during teaching and learning process that included investigation of types and functions of the speech acts produced by teacher. It was designed as a qualitative research. The subject of this research was an English teacher in SMAN 1 Kalirejo. The data were collected through recording. The data were analyzed through three cyclical steps: data reduction, data display, and conclusion drawing or verification. The results show that directives speech acts is mostly produced by the teacher than the other speech acts. This can be seen from the data that 33 utterances $(21.2 \%)$ are representative speech acts, 6 utterances (3.8\%) as expressive speech acts, 112 utterances $(71.8 \%)$ as directives speech acts, and 5 utterances (3.2\%) as commisive speech acts. The types and functions of directives speech acts proposed are need statement, bald imperative, embedded imperative, permission directive, and question directive.
\end{abstract}

Keywords: Teachers' speech acts, teaching and learning process

\section{Introduction}

Communication between teacher and students in teaching and learning process is regarded as an important element to perform an effective learning. Teachers will produce some utterance in order to convey the materials through their speech, when they communicate with their students. According to Bach (1994:1), in this typical situation of speech that involves the teacher as the speaker and the students as the hearers, the acts of the teacher's utterances are varied. Bach (1994:1) also stated that this is not only the matter of words which are uttered by teachers, but it also relates to teachers' intentions to hearers. The acts of speech of the speaker in the relationship to the hearers in communication are further called speech acts.

According to Searle (1969), speech act is the basic unit of language, the production of a token in the context of speech act. Then Curtis and O'Hagan (2005:48) state that the teaching which is carried out by language that is known as classroom speech act. The classroom speech acts affect the quality of verbal interaction in the classroom. Teachers will know the typical teaching behaviors when they use extensively in communicating with students. So, it will provide important information teachers. Besides, when teachers conduct the teaching process, they have some intentions in their speech directly or indirectly, and literal or non-literally spoken in their words. If students can comprehend what their teachers' say, it means that the use of speech acts is affective, for example: has no speech acts failure, although the intentions conveyed indirectly or no-literally. As stated Wajdi (2009), teachers' speech acts are extremely important, not only for the organization of the classroom but also for the acquisition processes of students.

In classroom communication, speech acts involves all verbal utterances used as a medium. According to Cazden (in Hickman, 2000), there are three general functions in language that make communication central in school, specifically in the classroom: teacher transmits curriculum, controls the communication, and reflects personal identify. It is 
assumed that the relationship of learning and language is the core of approaches to education. Teachers and students act upon the meaning they construct, toward use of language in classroom. Johnson (1997: 274) state that there are three modes of instructional functions of speech acts which are basic to teacher function in the classroom: control, organization, and motivation.

Moreover, according to Yule (1996: 53), one general classification system lists five types of general functions performed by speech acts. The first is declarations; they are those kinds of speech act that change the world via utterance. The acts of declaratives are approving, betting, blessing, christening, confirming, cursing, declaring, disapproving, dismissing, naming and resigning. The second is representatives that are those kinds of speech act that state what the speakers believe. The type include arguing, asserting, boasting, claiming, complaining, criticizing, denying, describing, informing, insisting, reporting, suggesting and swearing. The third is expressives which are those kinds of speech acts that state what the speakers feel. The acts are apologizing complimenting, condoling, congratulating, deploring, praising, regretting, and thanking. The fourth is directives which are those kinds of speech act that speakers use to get someone to do something. The type of directives speech acts are advising, asking, begging, challenging, daring, demanding, forbidding, insisting, inviting, ordering, permitting, recommending, requesting and suggesting. The last is commissives that are those kinds of speech act that speakers commit themselves to some future actions. The type of commissives speech acts are committing, guaranteeing, offering, promising, refusing, threatening, volunteering and vowing.

In relation to classroom speech acts, Searle (1969) claims that directives are speech acts that are frequently used in a classroom interaction. The teachers use it when they want students for doing something. Another theory of directives also proposed by Evin Trip (1976), states that there are some functions of directives speech acts: needed statement, bald imperative, embedded imperative, permission directives, question directives, and hint directives.

Considering the explanation above, the present study focuses on classroom interaction during teaching and learning process including investigation of types of the speech acts produced by teacher and functions of the speech acts produced by teacher.

\section{Method}

This research was designed as a qualitative research since the source of the data was the teaching and learning activity in naturalistic environment of the classroom. The researcher observed linguistic behaviors of teachers in a classroom context. The subject of this research was an English teacher who teaches English in senior high schools of SMAN 1 Kalirejo, Lampung Tengah.

In this study, the researcher only observed the speeches, especially the speech acts produced by the teacher. So, there were no speeches from the students observed. The data were collected through recording. Then, they are analyzed using Miles and Huberman's (1994) interactive model of data analysis. The data would analysis through three cyclical steps, namely: data reduction, data display, and conclusion drawing/verification. The researcher transcribed the utterances occurring in the conversation or interaction of teacher to students in the classroom, before selecting and reducing the utterances. Each of the selected utterances was entered into a profile in which all of its relevant characteristics are specified. Then, the data were classified and categorized based on specified characteristics. 


\section{Discussion}

This study was conducted in SMAN 1 Kalirejo. As non-participant, the researcher observed the teacher in the classroom. The researcher followed the teacher for the beginning until the end of the classroom. The researcher observed and recorded all of what the teacher and students said in the classroom. In this study, the researcher only transcribed the teachers utterances when the teacher and students discussion in the class. So, the audio recorded was not fully transcribed. After having the data and transcribed the, the researcher analyze speech acts produced by the teacher in the classroom. The speech acts identified was classified into five categories, namely: declarations, representatives, expressives, directives, and commissives. In terms of frequency of occurrence, the type of speech acts that occurred frequently in the classroom can be seen on the Table 1 below:

Table 1. Teacher's Speech Acts Production

\begin{tabular}{|l|c|c|}
\hline \multicolumn{1}{|c|}{ Speech Acts } & Utterances & Total Percentage \\
\hline Declarations & 0 & $0 \%$ \\
\hline Representatives & 33 & $21.2 \%$ \\
\hline Expressives & 6 & $3.8 \%$ \\
\hline Directives & 112 & $71.8 \%$ \\
\hline Commissives & 5 & $3.2 \%$ \\
\hline Total & 156 & $100 \%$ \\
\hline
\end{tabular}

Based on the table, the total production of teacher's speech acts in the classroom are 156 utterances. In the classroom, teacher did not production declarations speech act, she only produced representatives, expressives, directives, and commissives speech acts. There are 33 utterances $(21.2 \%)$ representatives speech act, 6 utterances $(3.8 \%)$ expressive speech act, 112 utterances $(71.8 \%)$ directives speech act, and 5 utterances $(3.2 \%)$ commisives speech act of the teacher.

\section{Type of the Teacher's Speech Acts}

Table 1 above shows that the teacher produced directives speech acts mostly. According to Searle (1969), the directives speech acts produce an effect through some actions that is done by the hearer. From the collected, the teachers created the type of directives speech acts such as asking, requirement (command and order), and advisory (advice and suggest).

According to Searle (1979), in advisory type the teacher used certain expression. The expression used was "jangan" (it means "Don't"). "Jangan" was employed as a negative imperative, that was used to advice the students not to do certain unexpected action. For instance, the teacher uttered "jangan ngerumpi!" (Don't gossiping!). Then, the asking type of the teacher's speech acts were used to ask the students about something that were constructed in question form. It applied wh-question, and also yes-no question types. On one hand, the teachers constructed the question by applying the question words, namely: what, who, where, and how many. Those words put at the beginning or at the end of the questions. For examples, "what are main ideas of each paragraph?" and "how many paragraph did you get?" On the other hand, the teachers also employed yes/no questions type, namely: do and have. For examples, "do you understand my students?" and "have you finish my students?"

The last type of directives speech acts is requirement. The teacher commanded and ordered students for doing something. The utterance of teacher in command and order, such as: "raise your hand if you want to answer paragraph 5!', "read the biodata on page 1!", "listen to me, I want you to find an inspirational man!" and "paragraph 5, please!" Based on the types of directives speech acts, the existence of question, command, order, and advice in 
teaching and learning develops the role of the teacher as initiator and sustainer of the interaction in the classroom (Brown, 2001). Appropriate questioning in an interactive classroom can fulfill several different functions. According to Searle (1969:22), directives are frequent speech acts in classroom interaction. It happens because in the classroom, teacher often asks students to do something.

Another types of speech act which produced by teacher is representatives. According to Searle (1979), the one who produces the representative speech acts is seen to commit the truth of the expressed proposition. From the finding, there are many acts of representatives speech acts that teacher uses. For examples, in reporting something, the teachers restated the students' responds/answers. Then, in informing, the teacher used certain markers, such as: "already" and "for example". The other type of representatives is claiming. The teacher's utterance in claiming, for example: "this is my role". From teacher's utterance, she gave a claim for students that students had to follow her role.

The types of expressive speech acts produced by the teacher were apologizing complimenting, praising, congratulating, and thanking. In apologizing complimenting, the teacher used the expression "sorry". For example, "last week, I did not come to this class, I'm so sorry". It shows that teacher apologize for the students because she could not come to their class. Then, in praising expression, the teacher used the expression "like". The teacher likes the students' attitudes how they answer her question. For example, "I like you, Bagas". It means that teacher like Bagas because the teacher feel satisfied for Bagas' answer. In congratulating the students' attitudes, the teacher used the expression "good". The teacher agreed and felt satisfy on the students' answer (behavior) appeared on using "good". Toward thanking expression, the teacher used expression "thank you". For example, "thank you for your attention." Based on the teacher's utterance, it means that she said thank you because of students' attention in learning English.

Commissives speech acts are in term of offer and promise. Commissives speech acts commit the speaker himself/herself to do future actions (Searle, 1979). Toward this, the teacher used offering and promising utterances signaled by existence of "we will" and "next week". For examples, "we will continue speaking, not for today" and "next week, I would like you to have a presentation".

Based on explanation above, there are four types of speech act that produced by the teacher in this research namely, directives, representative, expressives, and commissives. Directives are mostly used by teacher, because she wants students for doing something.

\section{Function of the Teacher's Speech Acts}

Directives is mostly speech acts in classroom interaction that are used as a command, order, advice, request, warning, etc. (Searle, 1969:22). When teacher used directives speech acts in classroom, the functions of those is also used. Furthermore, Ervin Trip's concept (1976) on directives function was used. There are types and functions of directives speech acts which proposed. First, need statement type was used in classroom transactional setting which made the students do a request. Second, bald imperative were formed in imperative mode that was used by person who has higher statues or superior to a person who has lower status. Third, embedded imperative was indicated by interrogative form, the use of modals, and also mostly used in this research.

Fourth, permission directives occurred in interrogative sentence. Fifth, a question directive was in interrogative mode. Based on the result, it was the highest frequency of directives speech acts, and hint directives. The teacher mostly controlled and managed the classroom by giving a series of questions. Moreover, a question directive also has other functions, such as: to check the students' knowledge about certain information, and to task 
the students' ability to do something. The last is hint directives, which was formed in declarative that seem to be the same as need statement. In hint directives, speaker makes the request implicitly.

\section{Conclusion}

To conclude, in teaching and learning process, directives speech acts is mostly produced by the teacher than the others speech acts. This can be seen from the high percentage of 33 utterances (21.2\%) representatives speech act, 6 utterances (3.8\%) expressive speech act, 112 utterances $(71.8 \%)$ directives speech act, and 5 utterances $(3.2 \%)$ commisive speech act. So, it can be argued that the teacher is frequently asking the students for doing something. Asking the students to say a sentence, answering the questions, and following the teacher's instruction is common orders from the teacher. In the classroom, the expectation of the teacher when using directives speech acts is the students' compliance. The teacher tends to believe that the whole instructional process in the classroom with regards to direct and indirect speech act is to benefit the students.

The functions of the teacher's directives speech acts in this research are control, organizational, and motivational or evaluative functions, such as: to ask the students about certain information, to check the students' knowledge about certain information, to command the students, to request the students to do certain action, to check the students' understanding about certain information, to focus the students' attention, to ask the students ability to do something, to warn the students, to suggest the students in positive way, to ask permission, and to suggest the students in negative way.

Directives speech acts in the classroom is very useful for the teacher because it is used to manage and control the students' behavior during teaching learning process. Teacher's directives demand the students' compliance. Moreover, the teacher's directives are also good model for the students to learn pragmatics in the classroom.

This study also has some implications. For the teachers, it is better for them to reduce the use of need statement and direct imperative, because it does not contain the polite maker. It is suggested that the teachers should use indirect speech act in daily teaching as it will be a good model for the students in learning. By using indirect form of speech act, the teacher will be showing awareness and consideration to the students' value. Being clear in delivering a message is good for the students as the message can be recognized easily without an inference among the students. For students, it is necessary to make an inference about teachers' intention to gain a sense of what teachers intended to make. Then, students also have to make a comprehension of the teachers' utterances not only from the syntactic form but from the intentions of the sentences as well. So that they could comprehend and respond the utterance directly and appropriately to avoid speech acts failures.

\section{References}

Bach, Kent. 1994. Meaning, Speech Acts, and Communication. In Basic Topics in the Philosophy of Language, ed. Robert Harnish, 3-21. Englewood Cliffs, NJ: PrenticeHall.

Brown, H. Douglas. 2001. Teaching by Principles: An Interactive Approach to Language Pedagogy. New York: Addison Wesley Longman, Inc. $2^{\text {nd }}$ Edition.

Cazden, C. B. 1988. Classroom Discourse: The Language of Teaching and Learning. In Hickman, S. 2000. Social Significance of Pattern of Questioning in Classroom Discourse. http://cla.libart.calpoly. edu. Retrieved on May. 72015. 
Curtis, Audrey and Maureen O'Hagan, 2005. Care and Education in Early Childhood: A Student's Guide to Theory and Practice. New York. Routledge Falmer. Curtis, Audrey and Maureen O'Hagan, 2005. Care and Education in Early Childhood: A Student's Guide to Theory and Practice. New York. Routledge Falmer.

Ervin-Tripp, S.M. 1976. A Coefficient of Agreement for Nominal Scales, Journal of Educational and Psychological Measurement, 20 (1), pp: 37-46.

Hickman, S. 2000. Social Significance of Pattern of Questioning in Classroom Discourse. http://cla.libart.calpoly.edu. Retrieved on May. 72015.

Miles, Matthew B and Huberman, A. Michael. 1994. An Expanded Sourcebook: Qualitative Data Analysis, second Edition. London: Sage Publications.

Searle, J.R., 1969. Speech Acts. Cambridge: Cambridge University Press.

Searle, J. R. 1979. Expression and Meaning. New York: Cambridge University Press.

Wajdi, Majid. 2009. Observing Teacher's and Students' English: (Discourse analysis of the classroom). Retrieved [3th March, 2016], from https://hajrabali.files.wordpress.com/2009/12/lg-of-classroom-icole.doc

Yule, George. 1996. Pragmatics. Oxford: Oxford University Press. 